\title{
ON TERMS FOR CUTTING PLANTS AND NOSES IN ANCIENT SUMER*
}

\author{
MANUEL MOLINA and MARCOS SUCH-GUTIÉRREZ, Consejo Superior de \\ Investigaciones Científicas, Madrid
}

\begin{abstract}
Cuneiform sources frequently mention fugitives, people who have fled from their duties. ${ }^{1}$ In order to prevent desertion, the law codes provided rewards for returning a slave to his master (LU 17; LH 17) and punishments for those who hide a fugitive or facilitate his escape (LH 15, 16, 19; LE 50). Nevertheless, none of these provisions deal with the physical punishment of fugitives, and other legal texts rarely mention it.

One of these exceptional attestations is found on an Ur III tablet kept in the British Museum. The text, BM 107955, which comes from Umma, ${ }^{2}$ reads as follows.
\end{abstract}

\begin{abstract}
* We are grateful to the Trustees of the British Museum for their kind permission to publish the tablet BM 107955 and to cite unpublished texts. Abbreviations follow those of M. Sigrist and T. Gomi, The Comprehensive Catalogue of Published Ur III Tablets (Bethesda, Maryland, 1991), and W. Sallaberger and A. Westenholz, Mesopotamien: Akkade-Zeit und Ur IIIZeit, OBO 160/3 (Freiburg, Switzerland and Göttingen, 1999), with the following additions: $A A I C A B$ 1/1: J.-P. Grégoire, Archives administratives et inscriptions cunéiformes de l'Ashmolean Museum et de la Bodleian Collection d'Oxford, vol. 1, pt. 1 (Paris, 1996); ADTB: F. Ismail, W. Sallaberger, P. Talon, and K. van Lerberghe, Administrative Documents from Tell Beydar (Seasons 1993-1995), Subartu 2 (Turnhout, 1996); AWL: J. Bauer, Altsumerische Wirtschaftstexte aus Lagasch, Studia Pohl 9 (Rome 1972); CDA: J. A. Black, A. George, and N. Postgate, eds., A. Concise Dictionary of Akkadian, 2d ed., SANTAG 5 (Wiesbaden, 2000); ETCSL: J. A. Black, G. Cunningham, E. Robson, and G. Zólyomi, The Electronic Text Corpus of Sumerian Literature, http://www-etcsl.orient.ox.ac.uk/ (Oxford, 1998-); LEM: P. Michalowski, Letters from Early Mesopotamia (Winona Lake, Indiana, 1993); Montserrat: M. Molina, Tablillas administrativas neosumerias de la Abadía de Montserrat (Barcelona).
\end{abstract}

[JNES 63 no. 1 (2004)]

(C) 2004 by The University of Chicago.

All rights reserved.

0022-2968-2004/6301-0001\$10.00.
Copias cuneiformes, MVN 18 (Rome, 1993), and Tablillas administrativas neosumerias de la Abadía de Montserrat (Barcelona): Transliteraciones e índices, AulaOr-S 11 (Barcelona, 1996); Ontario 1: M. Sigrist, Neo-Sumerian Texts from the Royal Ontario Museum, vol. 1, The Administration at Drehem (Bethesda, Maryland, 1995); Ontario 2: M. Sigrist, Neo-Sumerian Texts from the Royal Ontario Museum, vol. 2 (in press, courtesy M. Sigrist); PAS: B. Alster, Proverbs of Ancient Sumer: The World's Earliest Proverb Collections (Bethesda, Maryland, 1997); RCU: P. Michalowski, "The Royal Corerspondence of Ur" (Ph.D. diss., Yale University, 1976); RJM: F. Joannès, ed., Rendre la justice en Mésopotamie: Archives judiciaires du Proche-Orient ancien (III ${ }^{e} I^{e r}$ millénaires avant J.-C.) (Saint Denis, 2000); SANTAG 6: N. Koslova, Ur III-Texte der St. Petersburger Ermitage, SANTAG 6 (Wiesbaden, 2000); SAT 2, 3: M. Sigrist, Texts from the Yale Babylonian Collections, vols. 1-2, Sumerian Archival Texts 2-3 (Bethesda, Maryland, 2000); SP: E. I. Gordon, Sumerian Proverbs: Glimpses of Everyday Life in Ancient Mesopotamia (Philadelphia, 1959).

${ }^{1}$ On fugitives, see now D. C. Snell, Flight and Freedom in the Ancient Near East (Leiden, 2001).

2 The Umma provenance is based on the spelling ge$\mathrm{en}_{8}(\breve{\mathrm{s}} \mathrm{A})$. The writing $\mathrm{en}_{8}(\breve{\mathrm{s}} \mathrm{A})$ is typical of Umma when used with the verbs ge-en $n_{8}$ and $\mathrm{en}_{8}-$ tar. The former is found, for example, in AnOr 12, p. 103, no. 4; Montserrat 326; TCL 5 6059; and in the unpublished tablets BM 106219, BM 106451, BM 106641; en en $_{8}$ tar is attested in SANTAG 6 20, BM 106451, BM 108094 (unpublished). 
Text

$\begin{array}{ll}1 & \text { IIm-ti-x } \\ 2 & \text { arád é-gal } \\ 3 & \text { mu-3-àm } \\ 4 & \text { ì-zàh-àm } \\ 5 & \text { NI.NAGAR-e } \\ 6 & \text { pa-ág̃ ì-zí-e } \\ \text { r1 } & \text { Á-zi-da } \\ 2 & \text { ba-an-túm-mu } \\ 3 & \text { igi ensí-ka-šè / ba-ge-en } \\ 4 & \text { mu }{ }^{\mathrm{d}} \text { Amar- }{ }^{\mathrm{d}} \text { Suen / lugal-e } U r \text {-bí-/lum } \\ \end{array}$

${ }^{1}$ Imti-x, ${ }^{2}$ slave from the palace, ${ }^{4}$ fled $^{3}$ for three years. ${ }^{5}$ (The) NI.NAGAR ${ }^{6}$ will cut (his) nostril(s) $\mathrm{r} 2$ (and) will bring him to ${ }^{\mathrm{r} 1}$ Azida. ${ }^{3}$ It has been stated before the governor. ${ }^{4}$ The year when AmarSuen destroyed Urbilum (AS 2).

\section{Commentary}

Line 1: Im-ti-x

We cannot offer an explanation for the third sign of this personal name. The sign is like an IB closed with a horizontal wedge in its upper part. Names beginning with IM.TI may be composed with the Akkadian verb mâdu "to be plentiful" (Im-ti-dam, Im-ti-da) or with the noun $i m d u$ "support" (Im-dì-lum, Im-dì-AN.NA), although neither possibility seems plausible in our text.

\section{Line 5: NI.NAGAR-e}

The word NI-NAGAR-e could be interpreted either as a verbal form in third sing. marû or as a personal name or a profession with ergative suffix. The only other attestation of NI.NAGAR known to us, in a similar context, rather points to the latter possibility:

${ }^{1}$ Ur- ${ }^{\mathrm{d}}$ Lama ${ }^{2}$ na-ab-bé-a ${ }^{3}$ Ur- ${ }^{\mathrm{d}}$ Nanše-ra ${ }^{4}$ ù-na-a-du ${ }_{11}{ }^{5}$ Gemé- ${ }^{\mathrm{d}}$ Dumu-zi-da ${ }^{6}$ tukum-bi ${ }^{\mathrm{r}}{ }^{1}$ g̃emé Ba-la-la-kam ${ }^{2}$ šu hé-na-bar-re ${ }^{3}$ NI.NAGAR ${ }^{4}$ na-kà-ab-tum-ma ì-dab ${ }_{5}^{5}$ Ba-la-la ${ }^{6}$ hé-na-ab-sum-mu ${ }^{7}$ na-mi-gur-re. "Thus says Ur-Lama: 'Say to Ur-Nanše ${ }^{3}$ that, (concerning) Geme-Dumuzida, if this slave-girl belongs to Balala, let him release her for him (= Balala). (The) NI-NAGAR took charge of (arrested ?) her in the nakabtum. Let him give her to Balala. (This matter) must not come up again!'” (Molina, Aula Orientalis 17-18 [2000-2001]: 228, no. 40).

If NA.NAGAR should be interpreted as a profession, ${ }^{4}$ it could be related to bulug 4 , possibly the instrument used by the NI.NAGAR "to cut the nostrils" (see below) of the fugitive..$^{5}$

\footnotetext{
3 See n. 37 below.

4 Other professions beginning with NI are: ì- $\mathrm{du}_{8}=$ $a t \hat{u}$ "door keeper" (W. Farber, “'Großpförtner Nedu' und ein Problem neubabylonischer Schreibertradition," ZA 66 [1976]: 261 ff.; A. Cavigneaux and F. Al-Rawi, "Le portier des enfers," RA 76 [1982]: 189 f.); in lexical lists, NI-gíd-gíd = bārûtu (AHw., p. 110, s.v. bārûtu "Arbeit, Weisheit usw. des Opferschauers"; $C A D$, vol. B, pp. 131 f., s.v. bārûtu "1. act of divination ...");
}

beginning with ì- "oil”, ì-sur = șāhitu $(A H w .$, p. 1074, s.v. șāhitu $(m)$ "Kelterer"; $C A D$, vol. Ș, p. 62, s.v. șāhitu "preparer of sesame oil") and ì-rá-rá = muraqqû "unguent maker" ( $A W L$, p. 335); ̀̀-zu, as variant of a-zu = as $\hat{u}$ "physician" (Cavigneaux and Al-Rawi, "Le portier des enfers," p. 190).

5 According to H. Waetzoldt (NABU 1995/117), bulug $_{4}$ was a general term in Mesopotamia to designate sharp-pointed instruments. As a verb ("to sew"), 

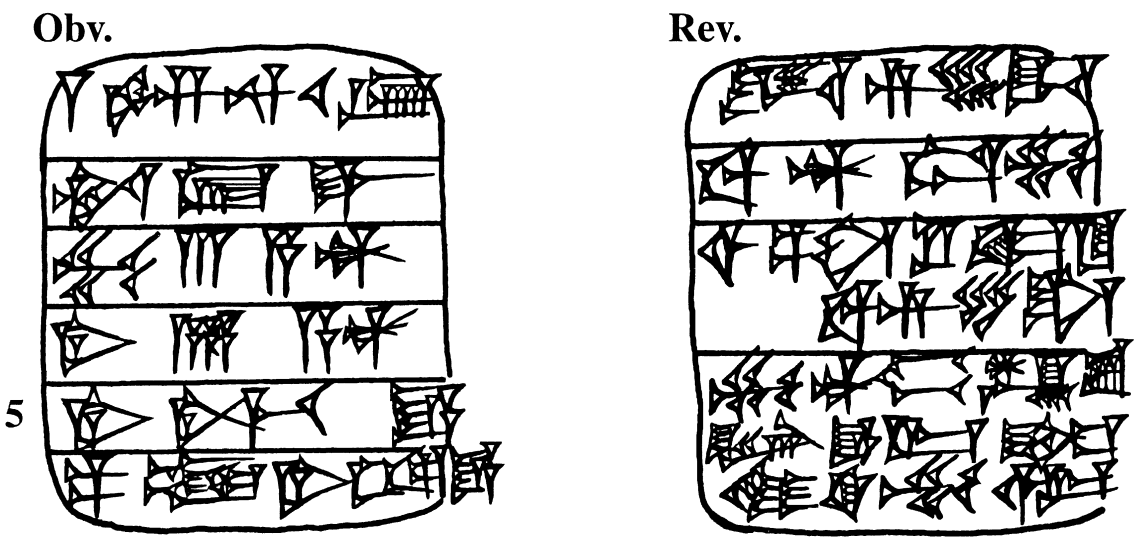

FIG. 1.-BM 107955 (1913-4-16-2787)

Line 6: pa-á $\tilde{g}-z i ́$

1. The sign ZÉ

In order to understand the meaning of the unusual Sumerian compound verb pa-ág̃ -zí, it would be useful to begin with some comments about ZÉ. This sign seems to have been introduced in the cuneiform system about the middle of the third millennium. It was mainly used to represent a syllable composed by a voiced or emphatic sibilant and the vowel e/i.

To the best of our knowledge, the sign zé first appears on a lexical tablet from Abu-Ṣalābīh (IAS 53 vi $7^{\prime}-8^{\prime}$ ) written as LAK539. ${ }^{6}$ It is rarely found in Ebla (see ARET 2, p. 165: x) and Tell Beydar (see ADTB, p. 41: 147). Nevertheless, a very different variant of zÉ (ARET 2, p. 166: ZÉ) is often attested in Ebla, especially in Semitic personal names (I-in-zé, İr-peš-zé, Zé-ba-da-ar, Zé-ba-da-mu, Zé-kam, etc.).

In Sargonic times, the use of the sign, usually also with the syllabic value in Semitic personal names, is widely attested, particularly in texts from Ešnunna, Girsu, and Tutub. The usual form in this period is LAK539, whereas LAK538 is rarely found (MAD 1302 r 5 [cf. MAD 2, p. 225], MC 427 obv. ii 4).

Conversely, in the Neo-Sumerian period, LAK $538^{7}$ is much more frequent than LAK539; ${ }^{8}$ the latter is still mainly used in Semitic personal names (Ṣi-lu-uš- ${ }^{\mathrm{d}} \mathrm{Da}-\mathrm{gan}, S \operatorname{i}$-la-šu, Te-zí-

bulug is rarely documented: $n$ kuš ba-rí-ga ba-ra-bulug (DCEPHE 234).

6 The text deals with temple officials and cultic personnel. These two lines, of uncertain reading (Dù.ZÉ / GAM+GAM.ZÉ), are paralleled by a lexical text from Fara (SF 57 x 15-16), which reads DÙ.DÉ / GAM+GAM.DÉ.

7 Attested, for example, in TCL 56049 r iv 1 ( $\breve{S} 41)$,

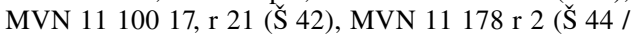
VIII), MVN 13706 r 20 (Š 44 / IX 29), MVN 11128

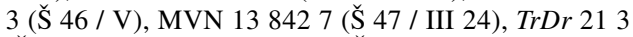

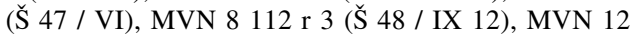
1212 (Š 46 / XI), MVN 13512 i 14, ii 25 (Š 46 / XII), MVN 11182 r iv 4, 12 ([ $\breve{S} /$ AS]), MVN 138454 (AS
2 / X 20), MVN 111564 (AS 5 / III 11), TCL 25505 r ii 15 (AS 5 / X 9), Ontario 11602 (AS 9 / XI 18), Montserrat $3423^{\prime}$ ([ ]), Montserrat 435 3', 6', 8' ([ ]), MVN 1189 r 2 (- / -).

8 Attested, for example, in MVN 31623 (ک̌ 39 / III), MVN 137042 (Š 44 / III 21), MVN 131217 (Š 44 / $\mathrm{X} 15), \operatorname{Tr} D r 86$ 7, r 5 (ك̌S 45 / VII 17), MVN 111822

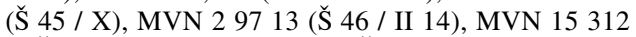

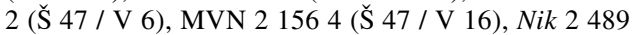
2 (Š 47 / IX 11), MVN 11182 r iv 13 ([Š / AS]), TCL 24682 r 1 (AS 1 / i 18), RA 8197221 (AS 5 / III), Montserrat 244 (AS 5 / IV 8), TCL 25504 r i 1 (AS 5 / X 9), MVN 15331 (AS 5 / XI), MVN 151792 ([AS / ŠS]), YOS 42382 ! (IS 1 / IX). 
in-Ma-ma, $S i-l i-{ }^{\mathrm{d}} A d a d$, etc. $)$ and toponyms $\left(H a-m a-z i^{\mathrm{ki}}\right),{ }^{9}$ and the former is preferred to write other words. ${ }^{10}$ It is in this period that we find the sign zÉ used for the first time with the meaning "to cut." Earlier, this action was denoted by the verb $\mathrm{SIG}_{7}$ ( $A W L$ 93, with other references in pp. 287-88).

In fact, in the Neo-Sumerian period zé replaces $\mathrm{SIG}_{7}$ in such contexts, except in Umma, where $\mathrm{SIG}_{7}$ is still used. In Ur III texts, then, $\mathrm{SIG}_{7}$ is phonetically written with the sign ZÉ when used in connection with plants or reeds: ${ }^{11}$ in this context, ZÉ is found in Drehem, Girsu, Ur, or Nippur and, to a lesser extent, also in Umma, whereas $\mathrm{SIG}_{7}$ is found only in Umma, The replacement of $\mathrm{SIG}_{7}$ by zÉ in Ur III is illustrated as follows: a) SIG7 and ZÉ are never found in the same text; ${ }^{12}$ b) the use of $\mathrm{SIG}_{7}$ as a verb in agricultural context is restricted to Umma Ur III texts (it never appears in texts from other sites), where zÉ is rarely documented; c) the action denoted by $\mathrm{SIG}_{7}$ and ZÉ in Ur III texts occurs in contexts dealing with the same kinds of plants and reeds.

Other cases in which ZÉ is used for $\mathrm{SIG}_{7}$ are, for instance: SANTAG 6 154, where the plural of the verb ti-(1) is written with the sign zÉ (7 PNs mu má-a-šè en-nu-g̃á ì-in-zé-ešàm), whereas in other Pre-Sargonic, Sargonic, and Ur III texts, the logogram SIG $_{7}$ is preferred; ${ }^{13}$ the expression ur-sag̃ ZÉ g̃á-ra "the shining hero" (Šulgi O: 83), where zÉ is to be understood as a writing for $\mathrm{SIG}_{7}$ (cf. Šulgi G: 15: é-kur-ra $\mathrm{SIG}_{7}$ mi-ni-g̃ar d Áš-ím-babbar-re "Ašimbabbar appeared shining in the Ekur").

\section{The reading of zÉ}

With regard to the reading of the sign zé in Sumerian, the frequent alternation of $\mathrm{ZI} / \mathrm{ZE}$ suggests zí in most cases. Thus, for the verb zÉ in agricultural contexts we find mu-zi in-

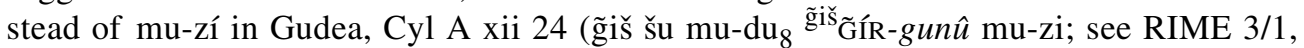
p. 77); in lexical lists we even have zi-i = ZI = nasāhnu, națāpu, baqāmu, barā̌̌ $u$ in Aa III/ 1 82-85 (MSL 14, p. 320), and zí, bu, zi = nasāḩu in SIG $_{7}$.ALAN XVIII 1-3 (MSL 16, p. 169).

Related to animals (see below), zi and zí are attested in the parallel texts BIN 3503 (1

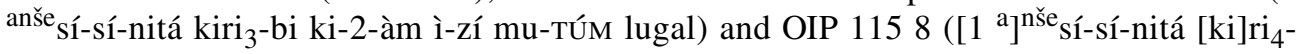
bi ki-2-àm ì-zi mu-Túm lugal). In toponyms, $\mathrm{Ha-ma-zí} \mathrm{is} \mathrm{preferred} \mathrm{in} \mathrm{Ur} \mathrm{III,} \mathrm{while} \mathrm{Ha}$ $m a-z i$ is usually found in pre-Ur III texts (see RGTC 2, pp. 72-73, ${ }^{14}$ and RGTC 1, p. 69); the alternation $\mathrm{Ha}-\mathrm{ma}-\mathrm{zi} / \mathrm{z} i$ is also attested in the sources of the letter RCU 2110 (RCU,

\footnotetext{
${ }^{9}$ In personal names and toponyms, LAK538 is also occasionally attested. LAK538 and 539 may even occur in the same text for two different personal names: TCL 25504 records Sii(LAK539)-lu-uš- ${ }^{\mathrm{d}} \mathrm{Da}$-gan (i 7) and $S i\left(\right.$ LAK538)-li- ${ }^{\mathrm{d}}$ Adad (ii 19); MVN 11182 records Si(LAK538)-lu-uš- ${ }^{\mathrm{d}}$ Da-gan (r iv 12) and Zí(LAK539)na-na (r iv 13).

${ }^{10}$ LAK538 is used in the substantives ${ }^{\tilde{g} i s ̌ s}$ Zí-na, šà-zí, šáh-zí-da, dug zí-tu-ru-um and zí ("gall": Cyl. A x 23), although LAK539 is also sporadically attested. As a verb related to plants and reeds, zí is always written with LAK538 (there are very few exceptions, for example, TPTS 5684 [Š 33 / VI], Torino 26692 [AS 1]).

11 This was briefly suggested by J. Bauer, "Georgica
}

Sumerica," Or., n.s., 77 (1998): 123.

12 The only exception known to us is Torino 2690 ; one should note that according to the copy of the tablet, the reading of line 2 should be corrected into ${ }^{\tilde{g} i s ̌ s}$ dì ú hirin ${ }_{\mathrm{x}}{ }^{2}$-na? 8 sar-ta (instead of g̃iš ú zí 8 sar-ta).

13 For $\mathrm{SIG}_{7}$ as the plural of the verb ti-(1), see P. Steinkeller, "Notes on Sumerian Plural Verbs," Or., n.s., 48 (1979): 55 and n. 5; idem, "The Sumerian verb $\operatorname{lug}_{\mathrm{x}}$ (LUL)," SEL 1 (1984); 5; idem, "The Verb se 11 , 'to live', in Pre-Sargonic and Sargonic Nippur Texts," ASJ 7 (1985): 195.

14 The reference to H. de Genouillac, Trouvaille 69 7 has to be corrected into $\mathrm{Ha}-\mathrm{ma}-\mathrm{zi}^{\mathrm{ki}}$. 
p. 258). In personal names, we have, for example, Lú-gi-zí (MVN 242 env. iii' 2' [ugula]) and Lú-gi-zi (TCTI 23966 r 5 [ugula]). Finally, the vessel ${ }^{\operatorname{dug}_{z i ́}-t u-r u-u m}$ has a spelling with

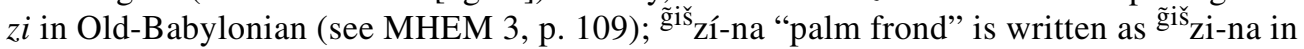
Hh 3360 (MSL 5, p. 123); and zí "gall" is rendered as zi/zí-i in Proto-Ea 287 (MSL 14, p. 43), Ea IV 168 (MSL 14, p. 362), and S ${ }^{\mathrm{b}}$ II 192 (MSL 3, p. 143).

On these grounds, we would suggest the reading zí for ZÉ, and $\mathrm{zi}_{\mathrm{X}}$ for $\mathrm{SIG}_{7}$ when used with the meaning "to cut." In the case of ZÉ and $\mathrm{SIG}_{7}$ as the plural of the verb ti-(1), we believe that the readings zé and $\mathrm{ze}_{\mathrm{x}}$ would be adequate respectively. ${ }^{15}$

For SIG $_{7} . \mathrm{LAGAB}$, a kind of supervisor for work performed in fields and orchards, ${ }^{16} \mathrm{G}$. Marchesi convincingly proposes the reading agar 4 -níg̃in ("the one who makes the rounds in / roams the agar"). ${ }^{17} \mathrm{SIG}_{7}$-a, attested in texts from other sites, seems to be a category of orchard worker (CST 263, TUT 146, etc.), whereas at other times it could be interpreted as a profession (SNATBM 487).

\section{The meaning of zí}

This matter was briefly treated by W. Sallaberger, ${ }^{18}$ who discussed the different ways of cutting reeds and suggested that the use of the verbs $\mathrm{SIG}_{7}, \mathrm{ku}_{5^{-}}(\mathrm{r})$, and zí could be related either to different kinds of cutting or to the use of different instruments. M. Civil, ${ }^{19}$ in turn, wrote that "zé = baqāmu is one of several terms used in Ur III texts to designate the removal of plants and weeds, the others being $\mathrm{ku}_{5^{-}}(\mathrm{r})$, bù-(r), and $\mathrm{SIG}_{7}-\mathrm{a}$." When in the context of fleece, Waetzoldt pointed out that it means "to shear" (udu šà-bi zí-a, udu gú-bi zí-a). ${ }^{20}$

15 This is especially suggested by Proto Ea 413 ze-e $=\mathrm{SIG}_{7}$ (MSL 14, p. 48); the variant še used in Pre-Sargonic and Sargonic Nippur texts points also to a final vowel e. Note that $\mathrm{ze}_{\mathrm{x}}\left(\mathrm{SIG}_{7}\right)$ as plural of ti-(1) is not restricted in Ur III texts to the city of Umma: in-da$\mathrm{Ze}_{\mathrm{x}}\left(\mathrm{SIG}_{7}\right)$ is documented, for example, in CTMMA 1 13a 6-b 3 (Dr), SAT 2861 r 7 (Dr), NATN 842 r 2 (Ni, $\mathrm{Rk})$; sila-a $\mathrm{ze}_{\mathrm{x}}\left(\mathrm{SIG}_{7}\right)$-a is attested in $A U C T 1171 \mathrm{r} 4$ (Dr), AUCT 1178 r 9 (Dr), AUCT $12325^{!}$(Dr), AUCT 135411 (?), BIN 3500 r ii 6 (Dr), BRM 31732 (?), MVN 138783 (Dr), SAT 28615 (Dr), 966 3, r 11 (Dr), TPTS 11 r 9 (Dr). In these cases, animals are always the subject; if the text deals with any other kind of goods, the expression used is sila-a gál-la: AUCT 2168 2, Birmingham 284 r 2, 183 2, SNATBM 337 r 5, 394 r 24, $400 \mathrm{r}$ i 8,434 i $22,470 \mathrm{r} 9$. The alternation of /ze/ and /še/ is uncertain in some other cases: $a$ ) a text from Nippur records $n$ gu-lá (gi-NE) DN a-na-ab-še-dè ( $N R V N$ $165)$, but we are not sure whether še is here a variant for zí "to cut (reeds)" (gu-lá are a kind of bundle of reeds that have been already cut); $b$ ) ga- $\mathrm{SIG}_{7}$-a, as proposed by M. Stol ("Milch(produkte). A. In Mesopotamien," RLA 8 [1993]: p. 193) and followed by R. K. Englund ("Regulating Dairy Productivity in the Ur III Period," Or., n.s., 34 [1995]: 419), could be a variant for ga-še-a, although this matter deserves further study.

16 SNATBM 511 records the work performed in fields and is sealed by A-a-kal-la dumu Ma-an-ba sagi
dŠará; this A-a-kal-la dumu Ma-an-ba is designated as $\operatorname{agar}_{4}$-nígin in other texts (see, for example, OrSP 4749 431: collations in Oriens Antiquus 17 [1978]: 51). According to OrSP 47-49 501, the function of the $\operatorname{agar}_{4}$-níg̃in could be performed by several members of the same family (PN, 3 PNs, dumu-ni-me, agar $_{4}$-níg̃in a-šà lugal-me). The position of the agar $_{4}$-níg̃in was probably high: occasionally he brings animals or textiles for the mu-Túm of deities (Rochester 118, MVN 16637 , etc.).

17 G. Marchesi, "Alleged $\mathrm{SIG}_{7}=$ agar $_{4}$ and Related Matters," Or., n.s., 70 (2001): 313-17. Marchesi has also pointed out (personal communication) that the variant a-gàr nígin is already attested in the Ur III period in a text where a-gàr nígin are recorded together with

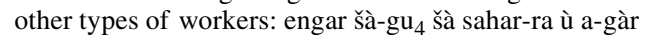
níğin-me (CST 263 v 25, xi 1 [Dr]: cf. Gomi, MVN 12, p. 106 ad loc.).

18 W. Sallaberger, "Zum Schilfrohr als Rohstoff in Babylonien," in B. Scholz, ed., Der orientalische Mensch und seine Beziehungen zur Umwelt: Beiträge zum 2. Grazer morgenländischen Symposion (2.-5. März 1989) (Graz, 1989), pp. 316, 325, n. 43.

19 M. Civil, The Farmer's Instructions: A Sumerian Agricultural Manual, AulaOr-S 5 (Barcelona, 1994), p. 70: 8.

${ }^{20} \mathrm{H}$. Waetzoldt, Untersuchungen zur neusumerischen Textilindustrie (Rome, 1972), pp. 12-14. 
TABLE 1

\begin{tabular}{|c|c|c|c|c|c|}
\hline & & & $\mathrm{ku}_{5}-\mathrm{r}$ & $\mathrm{zí} / \mathrm{zi}_{\mathrm{x}}\left(\mathrm{SIG}_{7}\right)$ & bù-r \\
\hline ú/g̃iš ĞÍR-gunû & $\begin{array}{l}\text { ašāgu "false carob (?)" } \\
\text { eddettu "boxthorn" }\end{array}$ & $\mathrm{f}$ & $*$ & & \\
\hline${ }^{(\tilde{g} i \mathrm{~s})}$ dìh & baltu "(a kind of thorny weed)" & $\mathrm{f}$ & $*$ & & \\
\hline úkul & išbabtu "(a kind of weed)" & $\mathrm{f}$ & - & $*$ & \\
\hline úLÁL.DU & "(a kind of weed)" & $\mathrm{f}$ & & $*$ & \\
\hline ú-g̃išhašhur & hašhūrakku"(a kind of weed)" & $\mathrm{f}$ & & $*$ & $*$ \\
\hline (ú) hirin $_{\mathrm{x}}$-na & lardu"(a kind of weed)" & $\mathrm{f}$ & & $*$ & - \\
\hline g̃iš KWU459/460 & "(a kind of weed ?)" & $\mathrm{f}$ & & & * \\
\hline ú- ${ }^{\tilde{g} i s ̌}$ HAR-an & "(a kind of weed)" & $\mathrm{f}$ & & $*$ & \\
\hline úKWU127 & "(a kind of rush)" & $?$ & & $*$ & \\
\hline úKWU127.A & "(a kind of rush)" & $\mathrm{f}$ & & $*$ & \\
\hline úKWU127.LAGAB & "(a kind of rush)" & $\mathrm{f}, \mathrm{fr}, \mathrm{o}$ & & $*$ & \\
\hline úKWU127.šÈ & "(a kind of rush)" & $\mathrm{f}, \mathrm{fr}$ & & $*$ & - \\
\hline úKWU127.šÈ.šE & "(a kind of rush)" & f & & & $*$ \\
\hline gi & qanûu "reed" & $\mathrm{f}, \mathrm{c}, \mathrm{o}$ & $*$ & $*$ & \\
\hline
\end{tabular}

In table 1 (further expanded in the Appendix below, pp. 9-16), we offer a chart of these verbs when they are used in connection with plants, reeds, and rushes removed either for the cleaning of fields (f) or from forests (fr), canebrakes (c), and orchards (o). ${ }^{21}$

The lexical evidence (zí = nasahu, baqāmu, etc.) and the context of Ur III texts suggest that the verb zí designates some kind of cutting plants. In the context of weeding and cleaning fields, this work was measured in sar and performed by un.íl, g̃uruš or šà-gu ( g̃emé are never attested for this task). Such work designated with the verb zí has to be different from those denoted by $\mathrm{ku}_{5}-(\mathrm{r})$ and bù-(r), since they often appear in the same text. Nowadays, depending on the kind and size of the plant, there are also three ways of removing weeds from fields:

a) Using only the hands, uprooting the plant. This is the action denoted by the verb bù-(r). ${ }^{22}$

b) Cutting or uprooting a woody or a thorny plant with a weedhook, a hoe, or a mattock. This should be the action denoted by the verb $\mathrm{ku}_{5}-(\mathrm{r})$.

c) Cutting the plant with a smaller instrument, a kind of sickle or billhook. This kind of sickle is different from the one used for mowing: it is broader, thicker, and resistant to accidental strikes against stones on the ground. That is probably the instrument mentioned in Limet, Métal, no. 19 AO $7873\left(10\left[(+x){ }^{\text {uruda }}{ }^{K I N}\right.\right.$ ú zí “ $n$ 'sickles' of copper to cut plants”) and in NATN 469 (10 ${ }^{\text {uruda }}$ KIN 1/3 ma-na-ta gi-zi zí "10 'sickles' of copper to cut $z i$-reeds"); it should be similar to the bar-hu-da, recorded in Emeš-Enten 209 (lú gi-zi barhu-da zí-[dè] g̃in gi-sumun-e dar-d[ar] "the man who sets about cutting zi-reeds with the

$21(*)=$ verb used to designate the removing of the plant; (-) = verb occasionally also attested.
22 See Civil, "Notes on the 'Instructions of Šuruppak'," JNES 43 (1984): 293, n. 17. 
barhuda, splits grown reeds"). ${ }^{23}$ The verb zí / $\mathrm{zi}_{\mathrm{x}}\left(\mathrm{SIG}_{7}\right)$ would designate then the cutting of plants with a small and hook-shaped tool at the lower part of the stem. ${ }^{24}$

The removing of rushes from fields, orchards, and forests was also indicated by the verb $\mathrm{Zí} / \mathrm{Zi}_{\mathrm{X}}\left(\mathrm{SIG}_{7}\right)$, although bù-(r) is found in some cases. In the case of reeds, when they were collected from fields, either the verb $\mathrm{ku}_{5}-\mathrm{r}$ or $\mathrm{zi} / \mathrm{zi}_{\mathrm{x}}\left(\mathrm{SIG}_{7}\right)$ are attested; the latter is also used to designate the cutting of reeds in orchards (DAS 410) or canebrakes (MVN 16 1255). ${ }^{25}$

Animals could also be the agent of an action denoted by the verb zí, as in the literary text Giš-gi 189: gi-zi gu -dè pa-bi zí-a níg̃-gu $_{7}$ máš-anše "the cattle eat (lit. 'cut' ${ }^{26}$ ) the leaves of the zi-reeds, fodder for (animals from) goats to donkeys." 27

\section{The verb pa-ág̃ -zí}

Returning to our text, the meaning of pa-ág "nostril” in the compound verb pa-ág̃ -zí is assured by Ugumu Sec. B: 9 (MSL 9, p. 67): pa-ág̃-kiri ${ }_{3}-\tilde{g} \mathrm{u}_{10}=n a$-hyi-ir ap-pi-ia. With regard to zí, we are again dealing with the verb discussed in the previous section. ${ }^{28}$ In this case, however, it probably denotes a kind of physical punishment, namely, cutting or marking the nose of the fugitive.

This compound verb is attested, to the best of our knowledge, in only three other texts. Unfortunately, two of them are badly preserved, and the interpretation of the third is far from clear:

(1) Montserrat 342: ${ }^{1^{\prime}}[\ldots]^{\top} \mathrm{x} \times x^{\top}[(\mathrm{x})]^{2^{\prime}}\left[i^{?}\right.$-zà $] \mathrm{h}^{?}$-àm / pa-ág̃ ba-an-zí ${ }^{3^{\prime}}$ [a]-rá-2-kam-šè ${ }^{4^{\prime}}$ é-ùr-ra inburu $_{\mathrm{x}}(\mathrm{PU}){ }^{5^{\prime}}$ igi A-kal-la ensí-šè ${ }^{\prime}$ ba-ge-en 6 . “. . . (PN) [had fl]ed? (and his/her) nostrils were cut. For a second time, he/she made a hole in the roof (and escaped). It has been stated before the governor."

(2) Diatribe B, Segm. B: 4 (Sjöberg, JCS 24 [1972]: 108; ETCSL): pa-ág̃ hé-en-zí lú abul [. . .] g̃iškim-bi hu-mu-un-X. "Whether he cuts (his) nostrils, whether the gatekeeper [. . .] asks for? the watchword."

(3) SP 2.76 (SP, p. 232; PAS, p. 61): anše gù an-mur lugal anše-ke ${ }_{4}$ pa-ág̃ an-zí ba-da-ra-ab-e $1_{11^{-}}$ dè-en-dè-en kašs-a g̃in-na-e-še. "A donkey brayed. The owner of the donkey pierced? its nostrils (to put a nose-ring? ). 'We are getting away from here! Run quickly!' he said."

Texts nos. 1 and 2 deal with humans. Text no. 2 is very damaged in this section, so it is difficult to ascertain the sense of some of the sentences; it is clear, however, that a negative description of Engardug's features is being made.

23 Cf. J. Deshayes, Les outils de bronze, de l'Indus au Danube (IV $V^{e}$ au II millénaire) (Paris, 1960), vol. 2, pls. 30-31, 45-46.

24 The action of pruning is never meant with the verb $\mathrm{zi} / \mathrm{Zi}_{\mathrm{x}}\left(\mathrm{SIG}_{7}\right)$. The only doubt could arise from texts recording a number of bales or bundles of reed, followed by the expression gi-(zi) $\mathrm{zi}_{\mathrm{x}}\left(\mathrm{SIG}_{7}\right)-\mathrm{a}$. It would seem that a different meaning from "the reeds have been cut" is required here. Nevertheless, in these cases either a place-name, which indicates where the action was performed, or the agent of the action (usually erén or a personal name) is always added. Thus, what is relevant in this expression is where the reeds were cut or who performed the action.

25 Reeds that have been cut may be classified as gi, gi-zi, and rarely gi-NE (Nik 2 189); gi-šid-da was prob- ably the expression used for "defoliated reed": see Waetzoldt, “'Rohr' und dessen verwendungsweisen anhand der neusumerischen Texte aus Umma," Bulletin on Sumerian Agriculture 6 (1992): 140, n. 55.

26 There is also a Spanish verb, "rozar," which may be used for either cutting plants, weeding, or grazing.

27 For these lines, see Civil, "Feeding Dumuzi's Sheep: The Lexicon as a Source of Literary Inspiration," in F. Rochberg-Halton, ed., Language, Literature, and History: Philological and Historical Studies Presented to Erica Reiner, AOS, vol. 67 (New Haven, Conn., 1987), p. 45 (hereafter Studies E. Reiner).

28 The verbal form pa-ág̃ ì-zí-e seems to exclude the interpretation of zí as zí-ir "to scratch, to tear up" (ì-zí-re would be expected), as Gordon suggests for the proverb 2.76 (SP, p. 232). 
Text no. 1, the first lines of which are poorly preserved, deals with a person who had fled for a second time. ${ }^{29}$ If our interpretation is correct, he was punished the first time with the cutting or marking of his nostril(s).

In the corpus of Ur III legal texts, we know only one other example of physical punishment of fugitives:

${ }^{1} \mathrm{I}_{\mathrm{Gu}}$-ú-gu ${ }^{2}$ arád Ur- ${ }^{\mathrm{d}}$ NUN.TÚG.PA-ka ${ }^{3}$ ba-an-da-zàh ${ }^{4}$ mu-dab ${ }_{5}{ }^{5}$ igi-ni in-g̃ar ${ }^{6}$ mu lugal u u a-rá2-ka ${ }^{7}$ ì-zàh-dè-na ${ }^{8}$ ga-hul-dè in-du ${ }_{11}$. "Gu' ugu, slave of Ur- ${ }^{\mathrm{d}}$ NUN-TÚG.PA, fled (and) was captured. He appeared (before the judges) and swore by the name of the king: 'the day I flee for a second time, may I be mutilated!" " (NRVN 1 1; Lafont, RJM, pp. 58 f., no. 19).

In non-Sumerian law codes, mutilations for different reasons are attested, albeit never concerning fugitives. These punishments are: ${ }^{30}$ to pluck out the hair (MAL A 59); to pluck out the eye (LH 193); to blind (LH 196); to cut off the ear (LH 205, 282, MAL A 4, 5, HitL 95, 99); to mutilate the ear (MAL A 59); to pierce the ears and thread them on a cord tied at the back (MAL A 40); to cut off the nose (MAL A 4, 5, 15, HitL 95, 99); to cut out the tongue (LH 192); to knock out a tooth (LH 200); to lacerate the face (MAL A 15); to cut off the breast (LH 194); to cut off the hand (LH 195, 218); and to castrate (MAL A 15, 20).

The problem of interpreting pa-ág -zí as a mutilation of the nose rests upon the fact that this verb is also used for equids. It is not reasonable to imagine that the donkey's nostrils are injured in the proverb quoted above (SP 2.76). The same difficulty arises in the interpretation of the parallel texts BIN 3503 and OIP 115 , where the appearance of an equid is described using a similar expression: $1^{\text {anše }}$ sí-sí-nitá kiri 3 -bi ki-2-àm ì-zí/zi, "a horse whose muzzle has been 'cut' on both sides (i.e., the nostrils)."

In the case of horses and donkeys, a kind of piercing or cutting could be described using the verb zí. It would be intended for the nose-rings to which reins were attached. ${ }^{31}$ This type of nose-ring for equids is well documented in iconography. ${ }^{32}$

Prisoners might also have these nose-rings, which were used for ropes. They are represented on reliefs, ${ }^{33}$ for example, and mentioned (serretum) in a text of Tiglath-Pileser I: "I subdued 30 of their kings. Like oxen I attached ropes to their noses (and) took them to my city." 34

Nose-ropes for people are also attested in Ur III texts (éš kiri ${ }_{3}$ ), particularly in some letter-orders:

29 In the edition of the text (Montserrat 342), Molina proposed the interpretation of the compound verb pa-ág̃ -zí as "to glide through a vent," being zé-(r) = nehelșu "to glide." In light of the text now discussed, this interpretation has to be corrected (see also the preceding footnote).

30 From M. T. Roth, Law Collections from Mesopotamia and Asia Minor (Atlanta, 1995).

31 In the case of the proverb SP 2.76, this action would be due to the need for controlling the ass.

${ }^{32}$ See M. A. Littauer and J. H. Crouwel, Wheeled Vehicles and Ridden Animals in the Ancient Near East
(Leiden and Cologne, 1979), pp. 30-31.

33 See references by I. J. Gelb, "Prisoners of War in Early Mesopotamia,” JNES 32 (1973): 73; F. R. Kraus, "Altbabylonische Quellensammlungen zur altmesopotamischen Geschichte," AfO 20 (1963): 154; U. MoorgatCorrens, "Zur ältesten historischen Darstellung der Assyrer," AfO 35 (1988): 114. A prisoner with a nosering may also be found on a carved vase coming from Uruk (?) and datable to the Sargonic period; see P. Amiet, Art d'Agadé au Musée du Louvre (Paris, 1976), pp. 25 and 88 .

34 A. K. Grayson, RIMA 2, A.0.87.2 26-27. 
${ }^{1}$ Ba-zi ${ }^{2}$ ù-na-a-du $11{ }^{3}$ Ur- $^{\mathrm{d}} \mathrm{Nanše} \mathrm{dumu-dab}{ }_{5}$ Lú- ${ }^{\mathrm{d}} \mathrm{Na}$-rú-a-ka-ra ${ }^{\mathrm{r} 1}$ éš kiri ${ }_{3}$-šè ${ }^{2}$ na-ba-dù. "Say to Bazi: 'He must not bind a rope to the nose of (= detain) Ur-Nanše, worker- $d .{ }^{35}$ of Lu-Naru'a' ", 36 (TCS 148 ).

${ }^{1}$ Na-ba-ša $6{ }^{2}$ ù-na-a-du ${ }_{11}{ }^{3}$ g̃emé Lú- ${ }^{\mathrm{d}}$ Dumu-zi-ke 4 in-tuku-a ${ }^{\mathrm{r} 1}$ [é]š kiri ${ }_{3}$-šè ${ }^{2}$ na-ba-dù ${ }^{3}$ gemé Du Du$_{11^{-}}$ ga-ni-zi-kam. "Say to Nabaša: "He must not bind a rope to the nose of (= detain) the slave-girl whom Lu-Dumuzi has married. She is the slave-girl of Dugunizi", (TCS 1 158; LEM, no. 129).

${ }^{1}$ Lú- ${ }^{\mathrm{d}}$ Utu ${ }^{2}$ ù Ur- ${ }^{\mathrm{d}}$ Nanše-ra ${ }^{3}$ ù-ne-a-du ${ }_{11}{ }^{4}{ }^{\mathrm{I}}$ Ur- ${ }^{\mathrm{d}}$ Lama ${ }^{5}{ }^{\mathrm{I}}$ Lú- ${ }^{\mathrm{d}}$ Nin-DAR-a $6{ }^{6}$ Lú-KA-gi-na ${ }^{\mathrm{r}} 1$ I Hé-ša 6 $\mathrm{mu}^{2}$ éš-kiri ${ }_{3}$ nu-ur ${ }_{5}-\mathrm{re}^{3}$ šu ha-bar-re. "Say to Lu-Utu and Ur-Nanše: ${ }^{37}$ "they must not fasten ${ }^{38}$ the nose-rope to (= detain) Ur-Lama, Lu-Nindara, LuKagina (and) Hešamu. Let them release (these people)!"” (Pettinato, Oriens Antiquus 7, p. 169, no. 1; LEM, no. 138).

We are not sure whether in these texts éš kiri $_{3}(-$ šè $)-$ dù/ur ${ }_{5}$ is to be understood literally ("to bind a rope to the nose") or ad sensum ("to detain"). It is only a hypothesis that the compound verb pa-ág̃ -zí could have any relation with a piercing performed on prisoners to insert a nose-ring. Yet this is the only link we can suggest with this verb, when it is used in connection with equids. In any case, pa-ág̃ -zí clearly denotes physical injury inflicted by using a small hook-shaped instrument on the noses of fugitives who were captured.

\section{APPENDIX}

In studying the use of the verb $\mathrm{zi}^{\prime} / \mathrm{zi}_{\mathrm{x}}\left(\mathrm{SIG}_{7}\right)$ in the Ur III texts, we collected the material concerning the removal of plants from fields, forests, and orchards. Our purpose was to ascertain which verb $\left(\mathrm{ku}_{5^{-}}(\mathrm{r})\right.$, bù-(r), $\left.\mathrm{zi}^{\prime} / \mathrm{zi}_{\mathrm{x}}\right)$ was used to designate the cutting or uprooting of each plant. We believe that this material could be useful for agricultural studies in the Neo-Sumerian period.

ú/g̃iš Ğ́́R-gunû = ád, eddettu "boxthorn"; kiši ${ }_{17}(-\mathrm{g} / \mathrm{k}), a \check{a} a \bar{g} u$ "false carob (?)"

Some different readings for these plants may be found in Ur III texts editions (ád, addú, gír, G̃ír, G̃íR-gunû, kiši ${ }_{17}$ ). Civil has pointed out (personal communication) that G̃íR-gunû is used for two different plants: ád (eddettu) and kiši ${ }_{17}(-\mathrm{g} / \mathrm{k})(a \check{s} \bar{a} g u) \cdot{ }^{39} \mathrm{In}$ fact, lexical lists offer both possibilities (Hh 3 432, $439=$ MSL 5, pp. 130-31; Diri II 250-51), but it is very difficult to ascertain which one is meant in Ur III texts.

${ }^{35}$ For dumu-dab 5 -ba, a category of worker, see A. Salonen, Agricultura Mesopotamica (Helsinki, 1968), p. 322 (the text quoted as MAH 16251 has been published by Sauren, MVN 2 59).

${ }^{36}$ For the construction PN-ra éš (absolutive) kiri $3^{-}$ šè-dù, see J. Krecher, "Neue sumerische Rechtsurkunden des 3. Jahrtausends," ZA 63 (1974): 191; B. Kienast, "Verzichtklausel und Eviktionsgarantie in den ältesten sumerischen Kaufurkunden," ZA 72 (1982): 32.

37 This Ur-Nanše could also be the one mentioned in the letter-order cited above (see Molina, "Neo-Sumerian
Letter-Orders in the British Museum. I," Aula Orientalis 17-18 [2000-2001]: 228, no. 40).

38 We interpret ur $_{5}=$ pâdum "to imprison with fetters (= acc.)": $A H w$., p. 808, s.v. pâdu(m); CDA, p. 260, s.v. pâdu(m).

${ }^{39}$ For kiši ${ }_{17}(-\mathrm{g} / \mathrm{k}$ ) (to be distinguished from

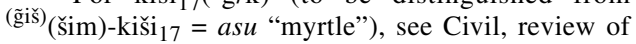
D. O. Edzard, ed., Heidelberger Studien zum alten Orient (Wiesbaden 1967), JNES 31 (1972): 223; R. D. Biggs, IAS, p. 70; Civil, Studies E. Reiner, pp. 47 f.; cf. also K. Maekawa, "Cultivation Methods in the Ur III 
The determinative preceding G̃íR-gunû is usually ú. In these cases, both readings úád and

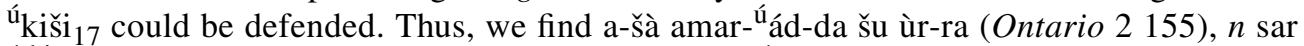
ú ki ${ }_{\text {kiši }}{ }_{17} n$-sar-ta (NATN 815), and $n$ guruš a-šà KA- ${ }^{\text {ḱkiši }}{ }_{17}-\mathrm{ke}_{4} \mathrm{a} \mathrm{du}_{11}$-ga (SAT 2 715).

According to Ur III administrative texts, "ú̃̃́lR-gunû was a very common weed, frequently recorded together with ${ }^{\tilde{g} 1 \tilde{s}}$ dìh. It was removed from fields mainly by male workers during the months III ${ }^{40} \mathrm{IV},{ }^{41} \mathrm{VI},{ }^{42} \mathrm{VII},{ }^{43} \mathrm{VIII},{ }^{44} \mathrm{IX},{ }^{45}$ and X; ${ }^{46}$ the task could be performed twice. ${ }^{47}$ There are some field names that include the term: a-šà KA- ${ }^{\text {kišsi }}{ }_{17}$ (see above), a-šà du ${ }_{6}{ }^{-}$ú G̃íR-

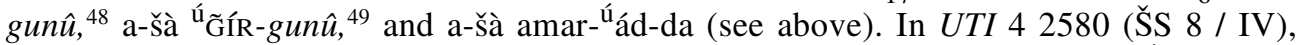
Agu, an Umma official in charge of products made of wood and reeds, ${ }^{50}$ receives ${ }^{\text {ú }}$ Ǵr $-g u n \hat{u}$, peš- $\operatorname{mur}_{7}$, and úKWU125.š̀ perhaps to be used as fuel.

With the determinative g̃iš, Ğír-gunû is attested, for example, in Gudea Cyl. A xii 24. In

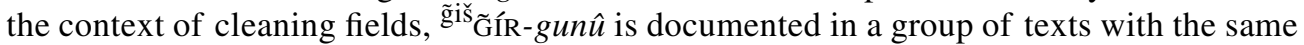
structure ( $n$ UN.íl a-šà GN g̃iš ${ }^{\text {ĞÍR- } g u n u ̂ ~} \mathrm{ku}_{5}$-a gána PN ugula PN [usually Lú- ${ }^{\mathrm{d}} \mathrm{Nanna}$ ]) and mostly dated to IS 2 IV-V. ${ }^{51}$ There is also a field bearing its name: a-šà amar- ${ }^{(\tilde{g} \text { išs }}{ }^{\text {Gír }}$ - $g u n \hat{u}$

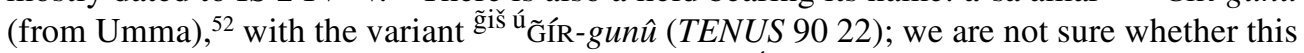
is the field recorded in Ontario 2155 as a-šà amar-úád-da (see above).

An Ur III collection of medical prescriptions mentions the use of the leaves (pa) and roots (e-ri ${ }_{\mathrm{X}}$-na) of ${ }^{\tilde{g} i s ̌} \tilde{\text { Gír }}$-gunû for healing purposes. ${ }^{53}$

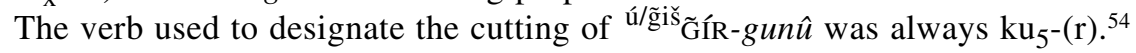

Period," Bulletin on Sumerian Agriculture 5 (1990): 123.

40 SAT 21046 r 7 (AS 7 / III).

41 SAT 319042 (ŠS 9 / IV 1).

42 UTI 321221 (AS 8 / VI 9).

43 SACT 2602 (AS 7 / VII 2), Torino 26922 (ŠS 9 / VII 2).

44 SAT 210277 (AS 7 / VIII), MVN 142493 (ॅ̌S

1 / VIII), SNATBM 502 i 3, 4 passim (ŠS 5 / VIII),

Torino 26942 (ŠS 9 / VIII 29), AAICAB 1/1 Ashm. 1911-139 2 (ŠS 9 / VIII 23), SAT 318812 (ŠS 9 / VIII).

${ }^{45}$ UTI 317284 (AS 7 / IX), SAT 316704 (ŠS 6 /

IX).

46 BIN 52372 ( ̌́ 44 / X 25).

47 ú G̃́́R-gunû a-rá-2-kam 12 sar-ta: AAICAB 1/1

Ashm. 1911-139 2 (ŠS 9 / VIII 23).

48 See, for example, SNATBM 35014 (AS 5), SAT 2 1027 r 9 (AS 7 / VIII), SAT 21114 i 7, r vii 33, viii 48 (AS 8), UTI 316384 (AS 9), UTI 53075 r 3 (AS 8), UTI 5346211 (AS 8?).

49 See, for example, ASJ 13231 , no. 74 r i 9 ( ̌ك 43), MVN 1182 (Š 48), SAT 21109 iii 70, r v 35 (AS 8), ASJ 13 222, no. 69 iii 18 (ŠS 5 / - 23), SNATBM 168 r 15 (IS 2), MVN $8181 \mathrm{rii}^{\text {? } . ~ 3 ' ~([~]) . ~}$

${ }^{50}$ Hans Neumann, Handwerk in Mesopotamien (Berlin, 1993), pp. $135 \mathrm{f}$.

${ }^{51}$ SET 256 3, 10 (AS 1 / IV), UTI 635782 (IS 2 /
IV 19?), UTI 322602 (IS 2 / IV 22), UTI 532052 (IS 2 / IV 25), UTI 321713 (IS 2 / V 1), UTI 321862 (IS 2 / V 8), UTI 320613 (IS 2 / V 20), UTI 321195 (IS 2 / V 27), UTI 532062 (IS 2 / V 25).

$52 \mathrm{See}$, for example, SAT 2679 r 7 (AS 1 / VIIVIII), BIN 5235 r 12 (AS 1 / VIII), MVN 3223 r 1 (AS 1), Nik 21053 (AS 1), BIN 52178 (AS 2), BIN 52414 (AS 2), SNATBM 324 r 2 (AS 2), UTI 42543 4 (AS 6 / III), UTI 31830 r 13 (AS 6 / VII), SAT 2951 r 7 (AS 6), UTI 534185 (AS 6), UTI 31812 r 7 (AS 7 / II), UTI 31728 r 6 (AS 7 / IX), UTI 427688 (AS 7), UTI 53491 r 8' (AS 7), SAT 21109 ii 27, r v 39, vi 58 (AS 8), UTI 53476 r 5 (AS 8), UTI 53480 8, 10 (AS 8?), SAT $21109 \mathrm{r}$ iv 10, 19 (AS 8) (a-šà ú đ̃írgunû 〈a-šà〉 amar-G̃ír-gunû), UTI 4288812 (AS 9), UTI 534924 (AS 9), SAT 31319 r 8 (ŠS 2), TCL 5 5676 v 17' (ŠS 2), UTI 317484 (ŠS 2), SNATBM 502 r ii 11 (ŠS 5 / VIII), UTI 423973 (ŠS 5).

53 M. Civil, "Prescriptions médicales sumériennes," RA 54 (1960): 61-62: 47, 117, 129, and comments on p. 67: 47.

54 For example, MVN 132853 (AS 5), SNATBM 3242 (AS 2), SNATBM 351 r 4 (AS 5), SNATBM 437 r 3 (ŠS 1), TCL 55676 vi 23, 25 passim (ŠS 2), MVN 13364 4-5, r 11-12 (ŠS 3), Montserrat 2371 (ŠS 4), MVN 133653 (ŠS 5), Nik 21385 (ŠS 5), YOS 4225 i 3, 5 passim (ك̌S 5), UCP 9/2 66 (ك̌S 9), and texts quoted in the footnotes above. The restoration [ $\left.{ }^{\mathrm{u}} \mathrm{ki}\right] \mathrm{si}_{17}$ ! zí-a in UTI 42769 r 8 is probably erroneous. 
${ }^{(\tilde{g} i s ̌)}$ dìh, baltu, "(a kind of thorny weed)" $" 55$

It is nearly always written with the determinative giš, albeit some exceptions do exist. ${ }^{56}$ After ${ }^{\text {Ǵ }} I_{1}$-gun $\hat{u}$, it is the most frequently mentioned weed in Ur III administrative tablets; both weeds were often found in the same field. Their cutting is attested during the months VI, ${ }^{57}$ VII, ${ }^{58}$ and VIII. ${ }^{59}$

As in the former case, the verb used to designate its removal was always $\mathrm{ku}_{5^{-}}(\mathrm{r}){ }^{60}$

úkul, išbabtu, "(a kind of weed)"

The reading of the name of this weed is based on the lexical evidence. ${ }^{61}$ Further proof for this reading appears in NATN 35 i 11', 13' and passim, which records ú ku kúl(GUL); the interpretation of KU.GUL as ${ }^{\mathrm{ku}} \mathrm{kúl}$ is confirmed in the same text by the rendering of ní $\tilde{\mathrm{g}}$-gul as ní g̃ ${ }^{\mathrm{ku}}{ }_{\mathrm{kúl}}(\mathrm{r}$ i 10,12$)$.

Ur III texts mention this plant in the context of cleaning fields also infested with ú $\tilde{\text { GíR- }}$ gunû, and ${ }^{\tilde{g} i s ̌}$ dìh; it grew together with ${ }^{\text {hirin }}{ }_{\mathrm{x}}-$ na. $^{62}$ The plant was removed during the months V, ${ }^{63}$ VII, ${ }^{64}$ and VIII. ${ }^{65}$ There is also a field bearing the name of this plant: a-šà ú ${ }^{\text {kul }} .{ }^{66}$ One text mentions its deposit in the workshop of a smith among a long list of products. ${ }^{67}$

The verb used to designate its cutting was mainly $\mathrm{zi}^{\prime} / \mathrm{zi}_{\mathrm{X}}\left(\mathrm{SIG}_{7}\right){ }^{68}$ albeit $\mathrm{ku}_{5^{-}}(\mathrm{r})$ is also often attested. ${ }^{69}$

úLÁL.DU, “(a kind of weed)”

The usual reading of the name of this plant as ukú has no basis. It is mentioned in the context of cleaning fields. There are also several toponyms that include its name: a-šà LÁL.DU

55 Civil, Studies E. Reiner, p. 5; cf. also Maekawa, "Cultivation Methods," p. 124. PDT 2918 i 20 (AS 6 /

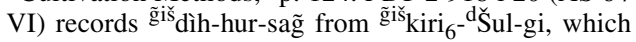
is probably a different kind of plant.

56 OrSP 47/49 3653 (AS 7), TPTS 4282 (AS 8). The reading údì in UTI 42604 r 29 (ŠS 2) should be corrected into ú LÁL.DU!

57 BIN 5220 1-2, 5-6 (AS 8 / VI).

58 UTI 322611 (AS 8 / VII 4), TPTS 5061 (AS 8 / VII 21), UTI 31849 1, 4 (AS 8 / VII 23), UTI 53255 1 (AS 8 / VII 24), SAT 32205 3-rev. 6 (- / - 20).

59 MVN 16941 (ŠS 1 / VIII 10), SAT 320962 (- / VIII), UCP 9/2 412 (- / VIII 8).

${ }^{60}$ For example, SNATBM 43714 (ŠS 1), MVN 13 364 2, r 9 (ŠS 3), Birmingham 260 r 20 (ŠS 4), MVN

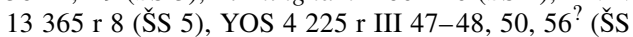
5), ASJ 18 82, no. 17 ii 2, 9 (ŠS 7).

${ }^{61}$ See $A H w .$, p. 393, s.v. išbabtu "etwa "Gras",; $C A D$, vol. I/J, p. 233, s.v. išbabtu "(a grass or a weed)."

${ }^{62}$ UTI 42882 r 21 (ŠS 4), CST 6212 (ŠS 9/ VII 7).
63 UCP 9/2 582 (ŠS 9 / V 1), TCNY 3432 ! (- / V

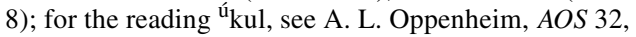
p. 163 Bab. 10.

64 SAT 2608 1, 5 (ॅ̌ 48).

65 SAT 2608 1, 6 (̌S 48), SAT 27002 (AS 2 / VIII), SAT 318862 (ŠS 9 / VIII 12), SAT 318992 (ŠS 9 / VIII 17).

66 MVN 910 r 7 (ॅ̌ 47).

67 UTI 53274 r i 5, 11 ([ ]).

68 See MVN 1613124 (AS 8), SACT 2584 (AS 8), SACT 2612 (AS 8), SACT 2128 5-6 (AS 8), SACT 2 132 5-6 (AS 8), UTI 316244 (AS 8), UTI 319722 (AS 8), UTI 426972 (AS 8), UTI 636914 (AS 8), UTI 428222 (ŠS 1), UTI 316962 (ŠS 3), UTI 42769 2 (ŠS 3), UTI 42882 r 21 (ŠS 4), ASJ 18 82, no. 17 r i 4 (ŠS 7)

69 See, for example, TPTS 4214 (AS 8), UTI 42398 3 (AS 8), MVN 14363 r 2 (ŠS 1), UTI 42555 r 13 (ک̌S 1), UTI 317383 (ŠS 2), UTI 424881 (ŠS 3). 
nu-ti, ${ }^{70}$ a-šà LÁL.DU nu-ti gu-la, ${ }^{71}$ a-šà LÁL.DU nu-ti bal-a-ri, ${ }^{72}$ ki-su ${ }_{7}$ LÁL.DU nu-ti, ${ }^{73}$ ki-su LÁL.DU nu-ti-gu-la, ${ }^{74}$ and e-sa-dúr-ra LÁL.DU nu-ti. ${ }^{75}$

The verb used to designate its cutting was $\mathrm{Zi}_{\mathrm{x}}\left(\mathrm{SIG}_{7}\right){ }^{76}$

ú-g̃išhašhur, hašhūrakku, "(a kind of weed)"77

To the best of our knowledge, this plant is attested only in six Ur III tablets. ${ }^{78}$ The verb used to designate its removal from fields was either $\mathrm{zi}_{\mathrm{X}}\left(\mathrm{SIG}_{7}\right)$, or bù-(r).

${ }^{(u ́}{ }^{\text {hirin }}{ }_{\mathrm{x}}$-na, $l a r d u$, "(a kind of weed)"”79

The reading hirin ${ }_{\mathrm{x}}$ for KWU318 was suggested by Civil. ${ }^{80}$ The interpretation of -na as a phonetic complement could be supported by Birmingham 261 1, 6, where the name of the plant is written with and without -na; furthermore, UTI 525143 and TCL 55675 v 23, 25, and passim, show that /a/ of -na is not /ak/, since the name of the plant is written here without Ú. In most cases, -na is written separately from hirin ${ }_{\mathrm{x}}$, although in some instances we find it inserted at the end of hirin ${ }_{\mathrm{x}}$ as a ligatur. ${ }^{81}$

Administrative texts mention this plant as being removed from fields, frequently together with ú Ĝ́r-gunû. TCL 55675 r i 17, 22 records plots infested with hirin ${ }_{\mathrm{x}}$-na, ú G̃íR-gunû, ú-

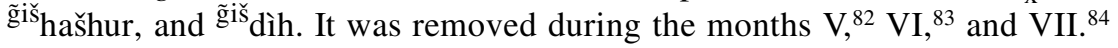

The verb used to designate its removing was mainly zí / zi $\mathrm{x}_{\mathrm{X}}\left(\mathrm{SIG}_{7}\right),{ }^{85}$ although bù-(r) is also attested. ${ }^{86}$

giš̌KWU459/460, "(a kind of weed ?)"

This plant is attested in only three texts. ${ }^{87}$ At least in one case (UTI 5 3185), the sign seems to be KWU459, which is not the sign for ANŠE (KWU460) ${ }^{88}$ commonly used in the

${ }^{70}$ For example, UTI 423023 (ك̌S 1), UTI 427635 (ŠS 1), UTI 42562 r 13' (ŠS 2).

71 For example, UTI 428956 (AS 9), UTI 42892 r 11 ( ̌́S 2).

72 For example, UTI 42391 3-4 (AS 8).

73 For example, SET 2632 (AS 7), TPTS 265 r 15 ([ ] $/ \mathrm{VI})$.

74 For example, TPTS 4524 (AS 9).

75 For example, UTI 425626 (ŠS 2).

76 SACT 2136 r 15 (ŠS 1), UTI 42557 r 10' (ŠS 3), Birmingham 26016 (ک̌S 4).

77 Civil, Studies E. Reiner, p. 51.

78 TCL 55675 r i 22, 24, 26, 28 (AS 5); YOS 4225 i 1, ii 27-28 passim (ŠS 5); SANTAG 6354 r 1 (- / VIII); JCS $31236510^{\prime}, 12^{\prime}, 14^{\prime}$ ([ ]); SAKF 82 r i 2, ii 4!, 8 ([ ]); Montserrat $4145^{\prime}$ ([ ] ]). UTI 4286811 (ک̌S 4) records ú- ${ }^{\text {gis }}$ pèš in context of cleaning fields; this attestation is perhaps to be understood as ú- ${ }^{\tilde{g} i s ̌}$ hašhur!

79 H. Limet, "Note sur les parfums en sumérien," RA 77 (1983): 187; Snell, Ledgers and Prices (New
Haven, Conn., 1982), pp. $230 \mathrm{f}$.

80 http://www.oi.uchicago.edu/OI/PROF/SUM/SLA/ Sumer.html (1997).

${ }^{81}$ MVN 3160 r 5 (Š 38), TCL 55675 v 27 (AS 5), NATN 956 (- / -).

${ }^{82}$ MVN 166362 (IS 2 / V 10), UTI 63546 r 1 (IS 2 ! / V 13).

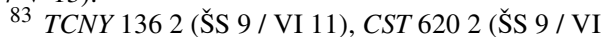
26).

84 TJAMC JES 1192 (ŠS 8), CST 6212 (ŠS 9 / VII 7), Torino 26932 (ŠS 9 / VII 8).

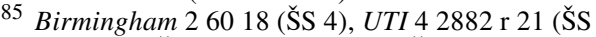
4), Nik 21384 (ŠS 5), SAT 315711 (ŠS 5), Birmingham 2611 (ŠS 6), SAT 318961 (ŠS 9) and texts in the footnotes above.

${ }^{86}$ SAT 28655 (AS 5) ("únirin ${ }_{\mathrm{x}}$ '(GAN)-na), UTI 6 3502 13, r 6 (AS 7), UTI 63810 II 18 (AS 8).

87 UTI 531853 (AS 9), UTI 53464 12, r 1, 5 (AS 9), UTI 635484 (AS 9). 
Ur III period. Together with KIš (KWU456) ${ }^{89}$ and KWU457, ${ }^{90}$ KWU459 is a variant of KWU460 ${ }^{91}$ and may also be used for g̃ìr. ${ }^{92}$ This plant should not be confused with ğ ǧs g̃ìr "foot fetters." 93

The name of this plant is documented in the context of cleaning fields. It is possibly also attested in the name of the field a-šà gána-KWU459. ${ }^{94}$

The verb used to designate its removing was bù-(r).

ú- ${ }^{\tilde{g} i s ̌ s}$ HAR-an, "(a kind of weed)"

The name of this plant is rendered in Ur III texts as HAR-an, ú-HAR-an, ${ }^{\tilde{g} i \check{s}_{\text {HAR-an; }}}$ the exceptions are: ú- ${ }^{\tilde{g} i s ̌ s}$ HAR (SAT 2480 r 9), ú-HAR-ra-an (UTI 63760 9', r 3), and Ú.AN.G̃Iš.HAR (MVN 194 3-4).

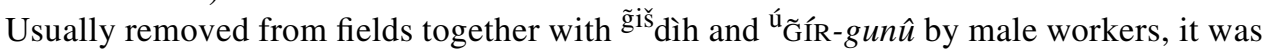
then transported either to reservoirs and canals ${ }^{95}$ (frequently from a-šà gána-Ur-gu to $\mathrm{I}_{7}$ sal $_{4}$-la), ${ }^{96}$ to the dub-lá- ${ }^{\mathrm{d}}$ Utu, ${ }^{97}$ or to the nakabtum. ${ }^{98}$ Only two texts inform us that the removing of the plant took place during the months VII and VIII. ${ }^{99}$

The verb used to designate its removal was always bù-(r). ${ }^{100}$

AN.SAHAR, "(a plant ?)":

This is attested in UTI 425141 (AS 8), in a context which seems to be of weeding. Its removal (?) was designated with the verb $\mathrm{ku}_{5^{-}}(\mathrm{r})$.

88 For the evolution of this sign, see Steinkeller, “The Name of Nergal," ZA 77 (1987): $162 \mathrm{f}$.

89 See, for example, Montserrat 11,2 ( $\breve{S} 30 /$ VI) ( gìr [obv. 3] is in this text rendered with KWU460, in order to distinguish it from ANšE $=$ KWU456), Hirose 663 ( ̌́ 47 / III 12; with KWU459 for anše [obv. 1-2]), HSS 442 7, r 4 (AS 1; with KWU460 for g̃ìr [r 7]), TUT 25 i 2, 3, 4, 5 ([?]); with KWU460 for anše [r iii 7, 8, 9, 10]), NATN 512 (IS 2 / XII).

90 For example, MVN 101173 ([ ] / X).

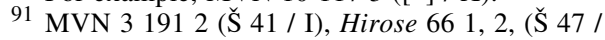
III 12), and the goddess-name Nin-ANŠE-lá in MVN 3 153 r 1 ( $\breve{S} 37$ / VI).

92 See, for example, MVN 446 r 6 (AS 4), MVN 3 2984 (̌̌S 9).

$93 A H w$. , p. 512, s.v. kursû(m) "eine Fessel," $C A D$, vol. K, p. 568, s.v. kurșî, "foot fetters, links"; see SET 1202 (- / II) (Lugal-nésa g̃-e lú g̃iš ğìr), and H. Limet, "Documents sumériens des Musées d'Art et d'Histoire, Bruxelles," Akkadica 117 (2000): 2 comm. to line 9. A different object seems to be ${ }^{\tilde{\text { giš }} \mathrm{KWU}}$ 456, which appears, for example, as part of boat equipment in SET 272 r 10 , coll. ASJ 8 (1996): 337 (ك̌S 42 / AS 6), TCL 55673 i 23, ii 16, iii 19, r i 9 (ك̌ 45 / AS 2), and possibly UTI 636893 (AS 6). A. Salonen, Die Wasserfahrzeuge in Babylonien, Studia Orientalia 8/4 (Helsinki, 1939): 101, interprets it as “'Schiffskrampen' (zum Festhalten der
Planken?)," connecting the object with the foot fetters. Nevertheless, the reading cannot be gìr here, since TCL 55673 records ${ }^{\tilde{g} i s ̌} \mathrm{KWU} 456$ along with KWU460 = g̃ìr in the personal name Gìr-né (obv. ii 22). Cf. also the object uruda KWU456: AAICAB 1/1 Ashm. 1911-184 (IS 2 / XII).

94 For example, TCL 55676 v 10', r ix.13' (ک̌S 2).

95 For example, MVN $1614753-5$ (ک̌S 1 / IX), MVN 161359 4-5 (ک̌S 2), UTI 53403 9-r 3 (ŠS 2), SAT 31574 1-3 (ŠS 5).

96 For example, SAT 21028 1-3 (AS 7) (here 〈gána-Ur-gu-ta〉), SACT 22 r 13-14 (ŠS 2), UTI 4 2851 5-r 1 ([ ]).

97 UTI 31743 3-5 (̌̌S 1), UTI 31686 3-5 (̌̌S 3), MVN 13309 4-r 7 (ŠS 5), SAT 31577 r 11-13 (ک̌S 5).

98 For example, TPTS 440 1-4 (ॅ̌ 42 / AS 6) (here g̃á-nun- ${ }^{\mathrm{S}}$ Šul-pa-è-ka na-kà-ab-tum g̃ar-ra), MCS 3 p. 90 112946 1-2 (AS 3), MVN 161013 1-3 (AS 7), UTI 3 2253 1-r 7 (AS 7), UTI 42561 r 19-21 (AS 8), MCS 3 p. 55112989 3-4 (AS 9), MVN 161344 1-3 (AS 9), MVN 161581 1-3 (AS 9), UTI 42633 2-4 (AS 9),

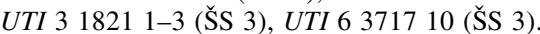

99 SAT 2385 (Š 44 / VIII), MVN 194 (ŠS 6 / VIII).

100 For example, UTI 530736 (AS 7), UTI 53152 4 (AS 9), SNATBM 437 r 1, 4 (ŠS 1), MVN 13364 r 14-15 (ŠS 3), UTI 63760 9', r 3 (the verb bù-r is here rendered as bu-r). The only exception known to us is 
úKWU127, úA.KWU127, úKWU127.A, úKWU127.LAGAB, úKWU127.š̀̀, úKWU127.š̀..šE

Different kinds of plants, commonly considered to be rushes, are written with the sign KWU127 in combination with other logograms. Civil ${ }^{101}$ and Waetzoldt ${ }^{102}$ have shown that at least in some cases these are different sorts of rushes and not merely orthographic variants of the same word. Thus, according to Waetzoldt, úKWU127.š̀ and A.KWU127 are recorded in the same text (DPOAE $1108 \mathrm{r}$ iv 3-6). To this Ur III attestation, the following examples can be added: ÚKWU127.šÈ and úKWU127.LAGAB are jointly recorded in VO 8/1

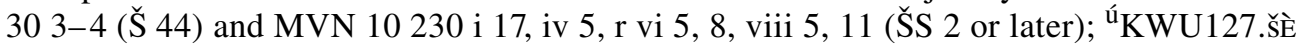
and úKWU127.š̀̀.šE are found in UTI 32082 3, r 11 (ŠS 1).

\section{úKWU127}

This is rarely attested in Ur III; ${ }^{103}$ it is possibly documented in the name of a field: [ašà . . .].TUR. ${ }^{\text {KKWU127. }}{ }^{104}$ MVN 14387 mentions three bales of this plant, with two bundles each, which were deposited on a pile of bricks.

The verb used to designate its cutting was $\mathrm{Zí}^{\prime} / \mathrm{zi}_{\mathrm{X}}\left(\mathrm{SIG}_{7}\right)$.

\section{úA.KWU127}

This is attested in three administrative texts ${ }^{105}$ and in the name of a field (a-šà ki-sumun A.KWU127). ${ }^{106}$ It is also mentioned in medical prescriptions. ${ }^{107}$ The plant was measured in gú.

\section{úKWU127.A}

This is documented in texts mainly dated to the reign of Šulgi. ${ }^{108}$ According to Civil, úKWU127.A is the older spelling of "KWU127.LAGAB. ${ }^{109}$ The plant was removed from fields and delivered in bales or bundles with different destinations: boatyards (probably for making ropes), ${ }^{110}$ the dam é-a-ga-RI, ${ }^{11}$ the g̃á-nun-da ${ }^{\text {giš }}$ kiri $_{6}$-A-ab-ba, ${ }^{112}$ and "to spread it out for a.-bread" (ninda-a-aš-šè ba-ra-ge-dè). ${ }^{113}$

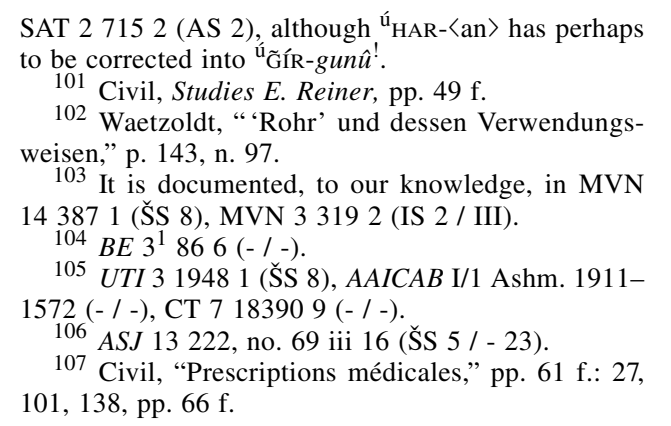

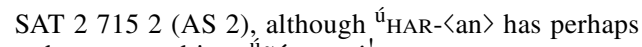
be corrected into "G̈ÍR-gunû

102 Waetzoldt, "'Rohr' und dessen Verwendungsweisen," p. 143, n. 97.

It is documented, to our knowledge, in MVN

43871 (ŠS 8), MVN 33192 (IS 2 / III).

${ }^{104} B E 3^{1} 866(-/-)$.

UTI 319481 (SS 8), AAICAB I/1 Ashm. 1911-

106 ASJ 13 222, no. 69 iii 16 (ŠS 5 / - 23). 101,138 , pp. $66 \mathrm{f}$.

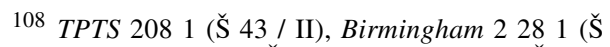

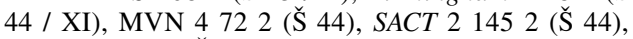
MVN 144171 (ک̌ 45 / AS 2), SAT 28883 (cf. SAT 3, p. 623) (AS 5), AAICAB 1/1 Ashm. 1924-687 2 (ŠS 6), Birmingham 21991 (IS 2 / XI), JCS 32230 3' ([?]).

109 Civil, "Studies on Early Dynastic Lexicography, I," Oriens Antiquus 21 (1982): 16.

110 TPTS 208 1-4 ( S 43 / II), MVN 14417 1-4

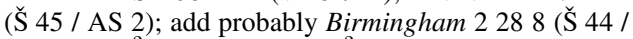
XI): dúr-bi? má-da-GA-šè ba 'ús (cf. CST 5853 [AS 2]: má-da-GA ak-dè).

111 Birmingham 2199 1-3 (IS 2 / XI).

112 AAICAB 1/1 Ashm. 1924-687 1-7 (ŠS 6).

113 SAT 2888 2-4 (AS 5). 
The verb used to designate its cutting was $\mathrm{Zi}_{\mathrm{x}}\left(\mathrm{SIG}_{7}\right) .{ }^{114}$

\section{úKWU127.LAGAB}

This is usually read as únumún on lexical grounds. ${ }^{115}$ It is occasionally written without determinative. ${ }^{116}$

This plant was mainly removed from forests, and sometimes also from fields and orchards. It was measured in sar, ${ }^{117}$ gú, ${ }^{118}$ or sa "bundles." ${ }^{119}$ Once removed, it was delivered to dams ${ }^{120}$ and boatyards, ${ }^{121}$ to build a kitchen, ${ }^{122}$ and to make ropes, ${ }^{123}$ sieves, ${ }^{124}$ and baskets. ${ }^{125}$ One basic source for study of this plant and úKWU127.š̀ is the archive of UrTAR.LUH and his son Ur-É-maš (see below). The usefulness of this plant is denoted by its inclusion in personal names and in the name of a goddess. ${ }^{126}$

The cutting of this plant is once designated with the verb zí. ${ }^{127}$

\section{úKWU127.šÈ}

It is commonly read as "úšub $5 .{ }^{128}$ Sometimes, TÚG is written instead of š̌̀. ${ }^{129}$

According to Ur III administrative texts, it was the most common rush. It grew mainly in forests but also in fields. It was measured in sar, ${ }^{130}$ gú, ${ }^{131}$ and sa "bundles." ${ }^{132}$ Once collected, it was delivered to various destinations: dams and canals, ${ }^{133}$ the (kun-zi-da)

114 AAICAB 1/1 Ashm. 1924-687 2 (ŠS 6), Birmingham 21992 (IS 2 / XI).

115 See MSL 3, p. 121: 283; MSL 10, p. 82, n. 9. F. Yildiz and T. Gomi have proposed gug $_{4}$ on the basis of UTI 3 1655: $n$ guruš u ${ }_{4}$-1-šè tir Inim- 'Šará?-ta gug ${ }_{4}$-ga ga $_{6}$ - gáa (see UTI 3, p. 50); M. Civil (personal communication) considers the reading gug $_{4}$ very problematic and suggests that -ga could be here a dittography for íl.

116 UTI 31655 (AS 8), ITT 582373 (?).

117 Orient 1692 r 19, 21 (AS 7).

118 MVN 14221 ('̌ 33? / VIII), MCS 411 BM 1054291 (?) (see H. Waetzoldt, "'Rohr' und dessen Verwendungsweisen,” p. 126: 3.3), RTC 306 r i 9', ii 8 ([ ]).

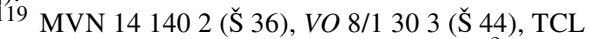
56036 i 11', ii 35, r i 30, 37, viii 25 (AS $4 /$ [ $\left.5^{?}\right]$ ) (here gín as 1/60 of sa), CTNMC 311 (AS 7), MVN 10230 i 17 (ŠS 2 or later).

${ }^{120}$ UTI 31655 5-r 7 (AS 8), MVN 161495 1-4 ( ̌̌S 2).

121 VO 8/1 303 (Š 44): see comm. to v 1-2.

122 CTNMC 31 1-2 (AS 7).

123 DAS 263 2-3 (AS 9 / IX), DAS 376 2-3 (AS 9 / IX), ITT 58237 3-4 ([ ]) (cf. collation of B. Lafont, $D A S$, p. 80: 263).

${ }^{124}$ MVN 10230 17-18 (ŠS 2 or later), TCL 56036 r i 33-39 (AS $\left.4 / 5^{\text {? }}\right]$ ) (reconstruction (ğiš [ma-an-sim$\operatorname{sig}_{5}$-lugal]) suggested by r vi 38 ).
125 TCL 56036 r i 27-32 (AS $\left.4 / 5^{?}\right]$ ).

126 Waetzoldt, “' 'Rohr' und dessen Verwendungsweisen," p. 143, n. 98. Ur- ${ }^{-} \mathrm{KWU} 127$. LAGAB is attested in MVN 3288 r 1 (ŠS 6 / XII or later).

127 DAS $4103^{\prime}$ ([AS 9?]) / IX -): for the reconstruction of the date, cf. texts in $\mathrm{n} .123$ above.

128 Cf. J. Bauer, "ZI×ZI.ŠE," Altorientalische Notizen $1987 / 39$.

129 UTI 53152 r 3 (AS 9), UTI 530053 (ŠS 2), and probably UCP 9/1 275 (Š 47 / VIII).

${ }^{130}$ UTI 320923 (ŠS 4), AAICAB 1/1 Ashm. 19241056 ii 9 (ŠS 3), Montserrat 2373 (ŠS 4).

131 UTI 636622 (ŠS 3), MVN 1610402 (ک̌S 4? / VI), MVN 10230 iv 5 (ŠS 3 or later), MVN 168362 ( ŠS 4).

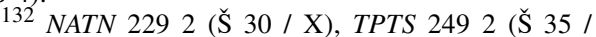
VIII) (here〈sa〉), Babyl 8 Pl. VIII Pupil 341 (Š 42 / AS 6), VO 8/1 304 (Š 44), TCL 55673 iii 17 (Š 45 / AS 3), TCNY 3251 (AS 1), MVN 1106 i 15, r i 13' (here 〈sa〉) (AS 3), MVN 133663 (AS 5), UTI 63829 r 1 (AS 8), CST 7571 (ŠS 2), MVN 1610651 (ŠS 7), MVN 10230 r vi 5, 8, viii 5, 11 (ŠS 3 or later), UTI 4 25803 (ŠS 8 / IV), DPOAE $1108 \mathrm{r}$ iv 4 (- / -).

${ }^{133}$ UTI 53017 r 1-3 (AS 9), UTI 53456 r 1-2 (ك̌S 1), TPTS 390 6-r 9 (ŠS 2), UTI 31789 1-5 (ك̌S 2), MVN 16976 7-r 4 (ŠS 3). 
dub-lá- ${ }^{\mathrm{d}}$ Utu, ${ }^{134}$ the nakabtum, ${ }^{135}$ the ganun? é-gibil, ${ }^{136}$ boatyards, ${ }^{137}$ and moon-festivals. ${ }^{138}$ It

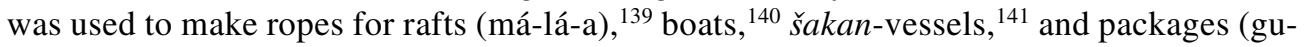
lá). ${ }^{142}$ One personal name also includes the name of this plant. ${ }^{143}$

An important archive for the study of this type of rush is the one of Ur-TAR.LUH and his son Ur-É-maš, supervisor of forests. ${ }^{144}$

The verb used to designate its removal was mainly $\mathrm{zi}_{\mathrm{X}}\left(\mathrm{SIG}_{7}\right),{ }^{145}$ although bù-(r) is also attested. ${ }^{146}$

\section{úKWU127.šÈ.šE}

This plant is to be considered a different type of rush from the former one, since both may appear in the same text (see above).

The few texts recording this plant mention it in the context of cleaning fields by male workers. ${ }^{147}$ There is only one text which records female workers transporting it to a canal. ${ }^{148}$

The verb used to designate its removal was always bù-(r). ${ }^{149}$

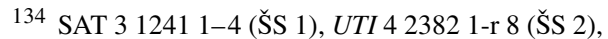
UTI $428844-5$ (ŠS 2).

135 UTI 53152 6-9 (AS 9), UTI 42393 1-4 (ŠS 1).

136 UTI 32082 r 10-11 (SS 1).

${ }^{137}$ UTI 63829 r $1-3$ (AS 8).

138 UTI 42781 6-r 9 (AS 8), UTI 63662 2, 4 (ك̌S 3), MVN $1610402-3$ (ŠS 4? / VI).

139 UTI 53152 r 1-3 (AS 9), SAT $314941-10$ (ŠS $4 / \mathrm{V})($. . la-[a-du] is probably to be corrected here into kéš-[rá-(a)]).

140 Babyl 8 Pl. VIII Pupil 34 1-r 1 (Š 42 / AS 6), TCL 55673 iii 17, 21 (Š $45 /$ AS 3), TCNY 141 1-2 (AS 5 / XI).

${ }^{141}$ TCNY 325 1-2 (AS 1).

142 CST 757 1-2 (ك̌S 2), MVN 161065 1-2 (ك̌S 7). For gu-lá "(a kind of package)," see Waetzoldt, " 'Rohr' und dessen Verwendungsweisen," p. 126: 3.4 (note NRVN 141 1-2 (S̆S 1 / XII 6], where 1001 of barley are equal to 26 gu-lá, so that 1 gu-lá $=3.81$ ).

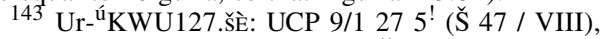
AAICAB I/1 Ashm. 1911-169 r 4 (ŠS 3 / ŠE.KIN-ku 5 ).

${ }^{144}$ See Steinkeller, "The Foresters of Umma:

Toward a Definition of Ur III Labor," in M. Powell, ed., Labor in the Ancient Near East, AOS, vol. 68 (New Haven, Conn., 1987), pp. 88 ff.

145 For example, UTI 427818 (AS 8), UTI 423933 (ŠS 1 / XII), UTI 636983 (ŠS 1), TPTS 3907 (ŠS 2), UTI 423822 (ŠS 2), UTI 426002 (S̆S 3).

146 See UTI 42779 5-6 (AS 8), UTI 53167 8, r 1 (AS 8), UTI 531527 (AS 9).

${ }^{147}$ SAT 21033 7-10, r 21-22, 24-25 (AS 7), UTI

53185 1-2, 6-7 (AS 9), UTI 63548 1, 2 (AS 9), SAT

$317821-2$ (ŠS 6).

${ }_{148}$ UTI 32082 1-3 (ŠS 1).

149 See footnotes above. 